\author{
Available online at http://bajas.edu.iq \\ https://doi.org/10.37077/25200860.2019.266 \\ College of Agriculture, University of Basrah
}

Basrah Journal of Agricultural Sciences

ISSN $1814-5868$

Basrah J. Agric. Sci., 32(Spec. Issue 2): 171-182, 2019

E-ISSN: 2520-0860

\title{
Effect of Planting Dates, Soil Mulching and Foliar Spraying Calcium on The Quantitative Yield Characteristics of Okra Plant Grown in plastic Greenhouse Kazem S. L. Alhamrani ${ }^{1}$, Abdullah A. Abdullah ${ }^{2}$ \& Diaa A. Taain ${ }^{2}$
}

1 Agriculture Directorate of Maysan, Ministry of Agriculture, Iraq

${ }^{2}$ Department of Horticulture \& Landscape, College of Agriculture, University of Basrah, Iraq

${ }^{1}$ Corresponding author e-mail: as.q249@yahoo.com

Received 19 September 2019; Accepted 18 November 2019; Available online 22 November 2019

\begin{abstract}
Maymunah Horticulture Station, Agriculture Directorate of Maysan. The experiment included 24 treatments of possible combinations between three sowing dates $\left(\mathrm{T}_{1}=15 / 12, \mathrm{~T}_{2}=31 / 12\right.$ and $\left.\mathrm{T}_{3}=15 / 1\right)$, two soil mulching treatments $\left(\mathrm{M}_{2}=\right.$ mulching the soil by black polyethylene, $\mathrm{M}_{1}=$ Without mulching) and four concentrations of calcium fertilizer $(\mathrm{Ca})\left(0,0.5,1\right.$ and $\left.1.5 \mathrm{ml}^{-1}\right)$, to study its effect on the quantitative yield characteristics of Okra plant cultivar "btayrh". The results showed that cultivated plants at date (15/1) showed significant increase in number of pods per plant, weight of pod, length and diameter of pod, the yield per plant and early yield compared to plants of dates (15/12 and 31/12). The cultivated plants in mulching soil were significantly higher in all studied quantitative yield characteristics. The sprayed plants with calcium $\left(1 \mathrm{ml} .1^{-1}\right)$ were superior in all studied quantitative yield characteristics. The interactions between the studied factors were significant in all the quantitative yield characteristics. The cultivated plants at date (15/1) with mulching and the sprayed by calcium fertilizer (1 $\mathrm{ml} . \mathrm{l}^{-1}$ ) gave the highest values of length $\&$ weight of pod, the yield per plant and early yield per plastic house $\left(6.31 \mathrm{~cm}, 4.08 \mathrm{~g}, 81.32 \mathrm{~g}\right.$ and $\left.0.180 \mathrm{Kg} . \mathrm{m}^{-2}\right)$ respectively. While the cultivated plants at (15/12) and un mulching soil and unfertilized gave the lowest values $\left(2.49 \mathrm{~cm}, 3.58 \mathrm{~g}, 38.50 \mathrm{~g}\right.$ and $\left.0.085 \mathrm{Kg} . \mathrm{m}^{-2}\right)$ respectively. In conclusion the present study indicated that growth and yield of okra cultivar increased by the addition of $1 \mathrm{ml} . \mathrm{l}^{-1}$ calcium which planting on 15 January and mulching soil.
\end{abstract}

Keywords: planting dates, Soil mulching, Calcium, greenhouse, Quantum yield, okra plant.

\section{Introduction}

Okra (Abelmoschus esculentus L.) belonging to the family Malvaceae, is one of the summery vegetable crop in Iraq and the world which grown extensively in the tropical, subtropical regions and warm temperate regions of the world (Saifullah \& Rabbani, 2009). The green pods, can be frozen or dried for consumption in winter, However Iraqi people prefer to cooked fresh green pod of Okra during the summer season (Al-Dajwi, 1996). In Iraq the total cultivated area in the year 2015 was about 16,750 ha with a total production of 124000 tons and a low production rate of 7.403 tons each ha. compared with other Arab countries (Arab Organization for Agricultural Development, 2016). The main reasons for the low rate of 


\section{Alhamrani et al ./ Basrah J. Agric. Sci., 32(Spec. Issue 2):171-182, 2019}

production of this plant in Iraq is represented by lack of modern techniques in the crop management of and determining the appropriate time of sowing date for plants, especially in plastic greenhouses. Determining the appropriate time of sowing date for okra plant in plastic greenhouses is very important especially after the spreading and expansion of protected agriculture in Iraq;. the statistics of the Ministry of Agriculture indicates that the number of plastic greenhouses planted with okra 759 houses with an area estimated at $500 \mathrm{~m}^{2}$ per greenhouse with a total production about 666 tons (Ministry of Agriculture, 2012). The seeds of okra plant needs warm conditions, where the appropriate degree of germination at $30-35^{\circ} \mathrm{C}$. Whereas the low temperature caused delay germination, slow growth and set irregular fruits (Matlub et al., 1989). Therefore temperature is one of important factors in determining the date of sowing and the success or failure the planting of okra crop especially in the plastic greenhouses. Ghodia et al. (2015) studied the appropriate time of sowing okra plant in Egypt during two seasons (2014 and 2015), they found that the best date time of seed sowing was on the mid of February. Whereas Atallah (2016) found a significant increase in pods length, weight and number per plant, in addition to hike the total crop yield per faddan for five cultivars of okra, when its sowing at two time dates periods (15/4 and 15/5) for two sequent seasons, he reported that the best time of date of seed sowing was on (15/4), where plant gave rise the high values of crop yield for two seasons in comparison with second date time. Zidan et al. (2018) observed when sowing okra plants in two time dates (20/12 and 10/1) a significant differences for seven cultivars under the conditions of plastic greenhouse in the number of pods per plant and overall plant yield. The pods characteristics were reduced when okra seeds planted at the first date compared to the second date, which recorded 68.5 pod. Plant ${ }^{-1}$ and 435.52 g. plant $^{-1}$. Plastic mulches play an important role in increasing soil temperature, roots growth, water and nutrients absorption, soil moisture conservation, control the weeds growth, and help to keep fruits clean. However, Carbon diaoxide accumulation can be avoided by planting cut holes through plastic mulch. Also, the plastic mater works to transfer salt away from the mulching area, which contributes to the early yield and increase the plants productivity (McCraw, 2003). Abdullah et al. (2017) reported that the greater yield of okra cultivar "Al-Khunessary" obtained when black plastic mulches were used, whereas Mohammed \& Saeid (2017) found there was no significance difference between three type of plastic color type of mulches used for fully mulched bed in compared with un mulched bed. Soil at Centre and South area have characterized by high content of clay, which effects on the of nutrients availability especially the calcium, which negatively reflected on crop yield (Abu Dhahi \& Yunis, 1988). Calcium is a major nutrient has many physiological functions for plant growth and development. It plays a key role in the build the cell wall structure (AISahaf, 1989). It gives flexibility and elasticity to the cellular wall, which facilitates the growth and expansion of the cells and increase the size and then increase the growth of the plant (Mengel et al., 2001). It helps to accelerate the transmission of carbohydrates and amino acids and build proteins by increasing absorbed nitrates. That affecting on division and elongation of cell, growth developing peaks and formation a new out growth (Marscher, 2012). In addition, the Calcium has ability in to reducing the 
phenomenon of flowers falling flowers in the early stages of plant growth. Where, Calcium help to strengthening the contact area with plant. Abo-EI-Hamd \& Abd EI-Wahed (2018) were succeeded to increase the pod length, diameter, weight, numbers and total yield when spraying the okra plants cultivar "Dokki" reported that with fertilizer contains a high percentage of calcium carbonate 79.19 $\%$ (the "Lithovit") in rate of 0.75 g. $1^{-1}$ for two seasons. The object of the present study was to evaluate the effect of sowing date, plastic mulches and spraying the plants with calcium on growth, development and yield of okra during the winter in Maysan Governorate, southern Iraq.

\section{Materials \& Methods}

The experiment was carried out during the agricultural season 2018/2019 in one of the non-heated plastic houses with dimensions 42 $\times 9 \mathrm{~m}$ and $378 \mathrm{~m}^{2}$ area belong to AlMaymunah- Horticulture Station, Agriculture Directorate of Maysan. The experimental area of the plastic house ploughed two times, and then cleaned and settled. Soil has been sterilized by using the normal solar radiation. Soil then ploughed once again. Experimental area then configured and divided into nine lines (40 m length, $40 \mathrm{~cm}$ wide and $30 \mathrm{~cm}$ high), the distance between line and another $50 \mathrm{~cm}$. The two lateral lines of the edge of the polyethylene cover $70 \mathrm{~cm}$. Animal manure had been added to cultivated area with rate of $6 \mathrm{~m}^{3}$. greenhouse ${ }^{-1}$. While the super-phosphate calcium $45 \% \quad \mathrm{P}_{2} \mathrm{O}_{5}$ at the rate of $27 \mathrm{~kg}$. greenhouse $^{-1}$. In order to prevent fungal infection the fungicide trade rail had been used with a rate of $900 \mathrm{ml}$ each greenhouse (100 $\mathrm{ml}$ per line), according to the instructions of the productive company. The animal and super-phosphate fertilizer were covered with soil. The drip irrigation system was used in this study. Every three contiguous lines were adopted as one sector then each line divided into two halves. One of half covered by black polyethylene, while the other left without cover. Same design was used for calcium spraying treatment. The okra seeds of the local cultivar "btayrh" had been used for. The seeds were planted directly in to contiguous lines prepared previously in the greenhouse. According to experimental design mentioned above, the number of sowing holes per each experimental area were 20 , located in the middle for line, with a 25 $\mathrm{cm}$ apart between each hole. The seeds were then sown 5-7 seeds per hole. The NPK fertilizer (8: 48: 12) were used to encourage the root formation when the true third leaf was appearance with the rate of $0.5 \mathrm{~g} .1^{-1}$. After one week the plants sprinkled with NPK (20: 20: 20) fertilizer once every week with a rate of $0.5 \mathrm{~g} . \mathrm{l}^{-1}$ for two weeks. All service operations were carried out for all treatments equally, where the plants irrigated according to the need for regular periods. Also a protective program to prevent insects and other diseases was adopted for all treatments. The structure of the greenhouse was coved with a polyethylene cover. While the greenhouse ventilation process was carried out by leaving the doors open. To prevent the insect penetration to greenhouse through door's opening, a saran net was installed. The solution of calcium fertilizer (CIFO) produced by Italian company was prepared that in three concentrations $(0.5,1$ and 1.5) ml. $\mathrm{l}^{-1}$, in addition to the comparison and sprinkled three times with each 10 days interval. Number, length, diameter and weight of pods were computed. Statistical analysis was carried out as a double-split experiment with three factors according to randomized complete block design (R.C.B.D.) with three replicates (Al-Rawi \& Khalaf Allah, 1980). 


\section{Results \& Discussions}

Findings showed that the highly significant effect on pods number per plant and pod's weight were obtained on sowing $\mathrm{T}_{2}$ and $\mathrm{T}_{3}$ date with a percentage of (16.13 and 1.34) and (28.58 and 4.31) \% respectively, table (1). Results also exhibited a percentage increase in pods number and weight when soil mulching with black polyethylene cover with a percentage increase of 6.10 and $\% 2.68$ respectively. Study also found that spraying the plants with $1 \mathrm{ml}^{-1}{ }^{-1}$ calcium fertilizer gave rise the best results of pods number and weight per plant in compare with the other three concentrations used in present work $(0$, 0.5 and 1.5) $\mathrm{ml}^{-1}$ and in a percentage (38.30, 10.75 and 14.37) and (4.87, 2.11 and $2.65) \%$ respectively. So, the sprayed plants with calcium with a concentration of $0.5 \mathrm{ml}^{-\mathrm{l}^{-1}}$ showed significantly increase in number of pods per plant and their weight compared to plants sprayed with a concentration $1.5 \mathrm{ml} . \mathrm{l}^{-1}$ and the percentage increase about (3.26 and $0.53) \%$ respectively.

In the case of the second treatment, a study revealed that the interaction between the factors under study, have been significance effect on pods number and weight. The data registered a significant effect between the third date of sowing and soil mulching, where the high value of pods number and their weight was recorded (17.12 pod. plant ${ }^{-1}$ and $3.96 \mathrm{~g} \cdot$ pod $^{-1}$ ), while plants sowed at the first date and in un mulching soil gave the lowest values in pods number and their weight (12.50 pod. plant ${ }^{-1}$ and $3.69 \mathrm{~g}$. pod $^{-1}$ ). So, the plants sowed at the third date and sprayed with calcium fertilizer with a rate of $1 \mathrm{ml}^{-1}$ gave the highest values of number and weight of pods about (19.03 pod. plant ${ }^{-1}$ and $3.98 \mathrm{~g}$. $\operatorname{pod}^{-1}$ ) respectively, whereas plants sowed at the first date and un sprayed with calcium fertilizer gave the lowest values in pod numbers and their weight (10.92 pod. plant $^{-1}$ and 3.63 g. pod $^{-1}$ ) respectively. The cultivated plants in the mulching soil and sprayed with the calcium fertilizer $1 \mathrm{ml}^{-1}$ gave rise the highest values of pods number and pod's weight (17.29 pod. plant ${ }^{-1}$ and 3.93g. pod $^{-1}$ ) respectively, but the cultivated plants in un mulching soil and un sprayed with calcium fertilizer gave the lowest values of pods number and pod's weight with 11.83 pod. plant $^{-1}$ and $3.64 \mathrm{~g}$. pod $^{-1}$ respectively. In the case of the third treatment (interaction of the third date of sowing, mulching and spraying the plants with $1 \mathrm{ml}^{-1} \mathrm{l}^{-1}$ of calcium fertilizer) it appeared that these factors have a significant effect on pods weight only, where the rate pod's weight gained around 4.08 g.pod ${ }^{-1}$, while the cultivated plants at the first date in un mulching soil, and not sprayed with calcium fertilizer produced the lowest value of pod's weight $3.58 \mathrm{~g}$. pod $^{-1}$.

Data on table (2) showed that the sowing dates have a significant effect on pod's length and diameter. The third date plants significant superiority compared to the first and second date plants in these two characteristics with an increase rate (44.24 and 23.49) and (39.53 and 4.05$) \%$ respectively. The second date of sowing had significant superiority compared to the first date of sowing with an increase rate (16.51and 34.10$) \%$ respectively. Also, the plants growing in the soil mulching with black polyethylene were gave rise a significant increase in the length and diameter of the pods compared with plant grown in the un- mulching soil with an increase rate about (8.97 and 2.86) \% respectively. The plants treated with foliar calcium fertilizer showed a significant effect on both length and diameter of pods. Results also revealed that best 


\section{Alhamrani et al ./ Basrah J. Agric. Sci., 32(Spec. Issue 2):171-182, 2019}

concentrations of foliar calcium fertilizer applied on plants was $1 \mathrm{ml}^{-1}{ }^{-1}$, where it gave a superior quality in comparison with plants three other concentrations in rate $(56,19.75$. and 35.56) and (17.91, 9.05 and 10.39) \% respectively. The plants sprayed with $0.5 \mathrm{ml}$. $1^{-1}$ calcium foliar fertilizer increase the percentage rate to (13.36 and 1.22) \% respectively, comparison with $1.5 \mathrm{ml} . \mathrm{1}^{-1}$ of calcium.

The second interactions between the factors of the study had significant effects except the interaction between the dates of sowing with the soil mulching was no significant in these two characteristics. The second interaction between the dates of sowing and calcium concentrations showed a significant effect on the length and diameter of the pod.

The third date sowed plants and the sprayed plants with concentration $1 \mathrm{ml}^{-1} \mathrm{l}^{-1}$ of calcium fertilizer gave the highest values of these two characteristics were recorded $(5.90 \mathrm{~cm}$ and $15.06 \mathrm{~mm}$ ) respectively, while the pods in the first date plants which not sprayed with calcium fertilizer gave the lowest values recorded $(2.57 \mathrm{~cm}$ and $8.59 \mathrm{~mm})$ respectively. The cultivated plants in the soil mulching with black polyethylene and the sprayed with concentration $1 \mathrm{ml}^{-1}$ of calcium fertilizer gave the longest and largest diameter were $(5.32 \mathrm{~cm}$ and $13.77 \mathrm{~mm})$ respectively, while the lowest length and diameter of the pod were recorded in the plants cultivated in un mulching soil and un fertilizer with calcium fertilizer were $(3.10 \mathrm{~cm}$ and $11.25 \mathrm{~mm})$ respectively.

In the case of the third treatment (interaction of the third date of sowing, mulching and spraying the plants with $1 \mathrm{ml}^{-1}$ of calcium fertilizer) it appeared that these factors have a significant effect on pods length only, while no significantly in the pods diameter, where the rate pod's length gained around $6.31 \mathrm{~cm}$, while the cultivated plants at the first date in un mulching soil, and not sprayed with calcium fertilizer produced the lowest value of pod's length $2.49 \mathrm{~cm}$. The results of table (3) showed that the dates of sowing had a significant effect on the yield per plant and early yield in greenhouse. The third date plants were significant superiority compared to the first and second date plants in these two characteristics with an increase rate (34.06 and 14.04) and (34.28 and 13.70) $\%$ respectively. Also, the second date plants were significant superiority compared to the first date plants with an increase rate (17.55 and 18.09) \% respectively. 
Alhamrani et al ./ Basrah J. Agric. Sci., 32(Spec. Issue 2):171-182, 2019

Table (1): Effect of planting dates ( $T$ ): $T_{1}=15 / 12, T_{2}=31 / 12$ and $T_{3}=15 / 1$, soil mulching $(M)$ : $M_{2}=$ mulching the soil by black polyethylene, $\mathrm{M}_{1}=$ Without mulching and foliar spraying calcium (Ca) on number of pods per plant and weight of pod for okra plant.

\begin{tabular}{|c|c|c|c|c|c|c|c|c|c|c|c|}
\hline \multirow{3}{*}{$\begin{array}{c}\text { Planting } \\
\text { dates } \\
\text { (T) }\end{array}$} & \multirow{3}{*}{$\begin{array}{c}\text { Soil } \\
\text { mulching } \\
\text { (M) }\end{array}$} & \multirow{2}{*}{\multicolumn{4}{|c|}{$\begin{array}{c}\left.\text { Number of pods (pod. plant }{ }^{-1}\right) \\
\text { Ca concentrations }\left(\mathrm{ml} .1^{-1}\right)\end{array}$}} & \multirow{3}{*}{$\mathrm{T} \times \mathrm{M}$} & \multirow{2}{*}{\multicolumn{4}{|c|}{$\begin{array}{c}\text { Weight of pod }\left(\mathrm{g} \cdot \mathrm{pod}^{-1}\right) \\
\text { Ca concentrations }\left(\mathrm{ml}^{-1}\right)\end{array}$}} & \multirow{3}{*}{$\mathrm{T} \times \mathrm{M}$} \\
\hline & & & & & & & & & & & \\
\hline & & 0 & 0.5 & 1 & 1.5 & & 0 & 0.5 & 1 & 1.5 & \\
\hline \multirow[t]{2}{*}{$\mathrm{T}_{1}$} & $\mathrm{M}_{1}$ & 10.75 & 12.65 & 14.18 & 12.44 & 12.50 & 3.58 & 3.72 & 3.76 & 3.71 & 3.69 \\
\hline & $\mathrm{M}_{2}$ & 11.09 & 13.58 & 14.62 & 12.88 & 13.04 & 3.68 & 3.74 & 3.79 & 3.73 & 3.74 \\
\hline \multirow[t]{2}{*}{$\mathrm{T}_{2}$} & $\mathrm{M}_{1}$ & 11.99 & 14.90 & 16.58 & 14.51 & 14.50 & 3.61 & 3.73 & 3.81 & 3.73 & 3.72 \\
\hline & $\mathrm{M}_{2}$ & 12.37 & 15.65 & 17.32 & 15.29 & 15.16 & 3.71 & 3.78 & 3.93 & 3.76 & 3.80 \\
\hline \multicolumn{2}{|c|}{ L.S.D.(0.05) } & \multicolumn{4}{|c|}{ N.S } & 0.33 & \multicolumn{4}{|c|}{0.03} & 0.02 \\
\hline \multicolumn{2}{|c|}{ Average of Ca effect } & 12.06 & 15.16 & 16.79 & 14.68 & & 3.69 & 3.79 & 3.87 & 3.77 & \\
\hline \multicolumn{2}{|c|}{ L.S.D.(0.05) } & \multicolumn{4}{|c|}{0.22} & & \multicolumn{4}{|c|}{0.01} & \\
\hline & & & & & & Average of dates effect & & & & & Average of dates effect \\
\hline $\mathrm{T} \times \mathrm{Ca}$ & $\mathrm{T}_{1}$ & 10.92 & 13.11 & 14.40 & 12.66 & 12.77 & 3.63 & 3.73 & 3.78 & 3.72 & 3.71 \\
\hline & & & $\begin{array}{c}\text { Average of mulching } \\
\text { effect }\end{array}$ & & $\begin{array}{c}\text { Average of mulching } \\
\text { effect }\end{array}$ \\
\hline \multirow{2}{*}{$\mathrm{M} \times \mathrm{Ca}$} & $\mathrm{M}_{1}$ & 11.83 & 14.52 & 16.30 & 14.32 & 14.24 & 3.64 & 3.74 & 3.81 & 3.73 & 3.73 \\
\hline & $\mathrm{M}_{2}$ & 12.30 & 15.80 & 17.29 & 15.04 & 15.11 & 3.74 & 3.84 & 3.93 & 3.81 & 3.83 \\
\hline \multicolumn{2}{|c|}{ L.S.D.(0.05) } & \multicolumn{4}{|c|}{0.32} & 0.20 & \multicolumn{4}{|c|}{0.02} & 0.01 \\
\hline
\end{tabular}


Alhamrani et al ./ Basrah J. Agric. Sci., 32(Spec. Issue 2):171-182, 2019

Table (2): Effect of planting dates ( $T)$ : $T_{1}=15 / 12, T_{2}=31 / 12$ and $T_{3}=15 / 1$, soil mulching $(M), M_{2}=$ mulching the soil by black polyethylene, $\mathrm{M}_{1}=$ Without mulching and foliar spraying calcium (Ca) on length and diameter of pod for okra plant.

\begin{tabular}{|c|c|c|c|c|c|c|c|c|c|c|c|}
\hline $\begin{array}{c}\text { Planting } \\
\text { dates } \\
\text { (T) }\end{array}$ & $\begin{array}{c}\text { Soil } \\
\text { mulching } \\
\text { (M) }\end{array}$ & \multicolumn{4}{|c|}{$\frac{\text { Length of pod }(\mathrm{cm})}{\text { Ca concentrations }\left(\mathrm{ml}^{-1} \mathrm{l}^{-1}\right)}$} & $\mathrm{T} \times \mathrm{M}$ & \multicolumn{4}{|c|}{$\begin{array}{c}\text { Diameter of pod }(\mathrm{mm}) \\
\text { Ca concentrations }\left(\mathrm{ml}^{-1} \mathrm{l}^{-1}\right)\end{array}$} & $\mathrm{T} \times \mathrm{M}$ \\
\hline $\mathrm{T}_{1}$ & $\mathrm{M}_{1}$ & 2.49 & 3.57 & 4.01 & 2.95 & 3.25 & 8.37 & 10.11 & 10.80 & 9.73 & 9.75 \\
\hline \multirow[t]{2}{*}{$\mathrm{T}_{2}$} & $\mathrm{M}_{1}$ & 2.83 & 4.02 & 4.96 & 3.27 & 3.77 & 12.42 & 13.00 & 14.12 & 13.17 & 13.18 \\
\hline & $\mathrm{M}_{2}$ & 3.15 & 4.40 & 5.32 & 3.63 & 4.13 & 12.83 & 13.33 & 14.37 & 13.40 & 13.48 \\
\hline $\mathrm{T}_{3}$ & $\mathrm{M}_{1}$ & 3.99 & 4.61 & 5.49 & 4.61 & 4.67 & 12.97 & 13.59 & 14.72 & 13.45 & 13.68 \\
\hline Average of & effect & 3.25 & 4.24 & 5.07 & 3.74 & & 11.44 & 12.37 & 13.49 & 12.22 & \\
\hline \multicolumn{2}{|c|}{ L.S.D.(0.05) } & \multicolumn{4}{|c|}{0.06} & \multicolumn{6}{|c|}{0.11} \\
\hline & & & & & & Average of dates effect & & & & & Average of dates effect \\
\hline \multirow{3}{*}{$\mathrm{T} \times \mathrm{Ca}$} & $\mathrm{T}_{1}$ & 2.57 & 3.75 & 4.18 & 3.07 & 3.39 & 8.59 & 10.22 & 11.17 & 9.77 & 9.94 \\
\hline & $\mathrm{T}_{2}$ & 2.99 & 4.21 & 5.14 & 3.45 & 3.95 & 12.62 & 13.16 & 14.25 & 13.28 & 13.33 \\
\hline & $\mathrm{T}_{3}$ & 4.19 & 4.76 & 5.90 & 4.70 & 4.89 & 13.10 & 13.72 & 15.06 & 13.60 & 13.87 \\
\hline $\mathrm{M} \times \mathrm{Ca}$ & $\mathrm{M}_{2}$ & 3.40 & 4.42 & 5.32 & 3.87 & 4.25 & 11.62 & 12.50 & 13.77 & 12.32 & 12.55 \\
\hline L.S.D.(0.05) & & & 0.1 & & & 0.07 & \multicolumn{4}{|c|}{0.18} & 0.13 \\
\hline
\end{tabular}


Results also exhibited a percentage increase in yield per plant and early yield in greenhouse when soil mulching with black polyethylene cover with a percentage increase of 9.24 and $9.32 \%$ respectively, compared to soil un mulching. The study also found that spraying the plants with $1 \mathrm{ml} .1^{-1}$ calcium fertilizer gave rise the best results of yield per plant and early yield in greenhouse in compare with the other three concentrations used in present work $(0,0.5$ and 1.5$) \mathrm{ml}^{\mathrm{l}^{-1}}$ and in a percentage $(46.77,13.26$ and 17.76$)$ and $(46.93,12.50$ and 17.07) \% respectively. So, the sprayed plants with calcium fertilizer with a concentration of $0.5 \mathrm{ml}^{-1}$ showed significantly increase in yield per plant and early yield compared to plants sprayed with a concentration $1.5 \mathrm{ml}^{-1}{ }^{-1}$ and the percentage increase 3.97 and 4.06 ) \% respectively.

In the case of the second interactions, a study revealed that the interaction between the factors under study, have been significance effect on yield per plant and early yield. The data registered a significant effect between the third date of sowing and soil mulching, where the high values of yield per plant and early yield were recorded $\left(67.99 \mathrm{~g}\right.$ and $0.151 \mathrm{Kg} . \mathrm{m}^{-}$ ${ }^{2}$ ) respectively, while plants sowed at the first date and in un mulching soil gave the lowest values in yield per plant and early yield (46.24g and $0.102 \mathrm{Kg} \cdot \mathrm{m}^{-2}$ ) respectively. So, the plants sowed at the third date and sprayed with calcium fertilizer with a rate of $1 \mathrm{ml}^{-1}$ gave the highest values of yield per plant and early yield $\left(75.73 \mathrm{~g}\right.$ and $\left.0.168 \mathrm{Kg} . \mathrm{m}^{-2}\right)$ respectively, whereas plants sowed at the first date and un sprayed with calcium fertilizer gave the lowest values in yield per plant and early yield (39.65 g and $0.087 \quad \mathrm{Kg} . \mathrm{m}^{-2}$ ) respectively. The cultivated plants in the mulching soil and sprayed with the calcium fertilizer $1 \mathrm{ml}^{-1^{-1}}$ gave rise the highest values of yield per plant and early yield (68.26 $\mathrm{g}$ and
$0.151 \mathrm{Kg} . \mathrm{m}^{-2}$ ) respectively, but the cultivated plants in un mulching soil and un sprayed with calcium fertilizer gave the lowest values of yield per plant and early yield (42.91g and $0.095 \mathrm{Kg} . \mathrm{m}^{-2}$ ) respectively. In the case of the third treatment (interaction of the third date of sowing, mulching and spraying the plants with $1 \mathrm{ml}^{-\mathrm{l}^{-1}}$ of calcium fertilizer) it appeared that these factors have a significant effect on yield per plant and early yield gained around (81.32g and $0.180 \mathrm{Kg} . \mathrm{m}^{-2}$ ) respectively, while the cultivated plants at the first date in un mulching soil, and not sprayed with calcium fertilizer produced the lowest values of yield per plant and early yield (38.50 g and 0.085 $\mathrm{Kg} . \mathrm{m}^{-2}$ ) respectively.

The results of the tables (1-3) showed that all the factors of this study and their second interactions and third interaction had a significant effect on the quantitative yield characteristics except the interaction between the dates of sowing and mulching, which was no significant effect in length and diameter of pod. 
Alhamrani et al ./ Basrah J. Agric. Sci., 32(Spec. Issue 2):171-182, 2019

Table (3): Effect of planting dates ( $T$ ) ): $T_{1}=15 / 12, T_{2}=31 / 12$ and $T_{3}=15 / 1$, soil mulching $(M), M_{2}=$ mulching the soil by black polyethylene, $M_{1}=$ Without mulching and foliar spraying calcium (Ca) on the yield per plant and early yield pod for okra plant.

\begin{tabular}{|c|c|c|c|c|c|c|c|c|c|c|c|}
\hline \multirow{2}{*}{$\begin{array}{c}\text { Planting } \\
\text { dates } \\
(\mathrm{T})\end{array}$} & \multirow{2}{*}{$\begin{array}{c}\text { Soil } \\
\text { mulching } \\
(\mathrm{M})\end{array}$} & \multicolumn{4}{|c|}{$\begin{array}{c}\text { Yield per plant }(\mathrm{g}) \\
\text { Ca concentrations }\left(\mathrm{ml} .1^{-1}\right)\end{array}$} & \multirow[t]{2}{*}{$\mathrm{T} \times \mathrm{M}$} & \multicolumn{4}{|c|}{$\begin{array}{c}\text { Early yield }\left(\mathrm{Kg} \cdot \mathrm{m}^{-2}\right) \\
\text { Ca concentrations }\left(\mathrm{ml}^{-1} \mathrm{l}^{-1}\right)\end{array}$} & \multirow[t]{2}{*}{$\mathrm{T} \times \mathrm{M}$} \\
\hline & & 0 & 0.5 & 1 & 1.5 & & 0 & 0.5 & 1 & 1.5 & \\
\hline \multirow[t]{2}{*}{$\mathrm{T}_{1}$} & $\mathrm{M}_{1}$ & 38.50 & 47.01 & 53.36 & 46.10 & 46.24 & 0.085 & 0.104 & 0.118 & 0.102 & 0.102 \\
\hline & $\mathrm{M}_{2}$ & 40.80 & 50.78 & 55.42 & 48.05 & 48.76 & 0.090 & 0.113 & 0.123 & 0.107 & 0.108 \\
\hline \multirow[t]{2}{*}{$\mathrm{T}_{2}$} & $\mathrm{M}_{1}$ & 43.25 & 55.57 & 63.17 & 54.13 & 54.03 & 0.095 & 0.123 & 0.140 & 0.120 & 0.120 \\
\hline & $\mathrm{M}_{2}$ & 45.88 & 59.19 & 68.03 & 57.52 & 57.65 & 0.101 & 0.131 & 0.151 & 0.127 & 0.128 \\
\hline \multirow[t]{2}{*}{$\mathrm{T}_{3}$} & $\mathrm{M}_{1}$ & 46.98 & 60.24 & 70.15 & 60.10 & 59.37 & 0.104 & 0.133 & 0.155 & 0.133 & 0.131 \\
\hline & $\mathrm{M}_{2}$ & 51.33 & 72.81 & 81.32 & 66.48 & 67.99 & 0.114 & 0.161 & 0.180 & 0.147 & 0.151 \\
\hline \multicolumn{2}{|c|}{ L.S.D.(0.05) } & \multicolumn{4}{|c|}{2.20} & 1.32 & \multicolumn{4}{|c|}{0.004} & 0.002 \\
\hline Average 0 & Ca effect & 44.45 & 57.60 & 65.24 & 55.40 & & 0.098 & 0.128 & 0.144 & 0.123 & \\
\hline \multicolumn{2}{|c|}{ L.S.D.(0.05) } & \multicolumn{4}{|c|}{0.88} & \multicolumn{6}{|c|}{0.002} \\
\hline & & & & & & Average of dates effect & & & & & Average of dates effect \\
\hline \multirow{3}{*}{$\mathrm{T} \times \mathrm{Ca}$} & $\mathrm{T}_{1}$ & 39.65 & 48.89 & 54.39 & 47.07 & 47.50 & 0.087 & 0.108 & 0.120 & 0.105 & 0.105 \\
\hline & $\mathrm{T}_{2}$ & 44.56 & 57.38 & 65.60 & 55.82 & 55.84 & 0.098 & 0.127 & 0.145 & 0.124 & 0.124 \\
\hline & $\mathrm{T}_{3}$ & 49.15 & 66.53 & 75.73 & 63.29 & 63.68 & 0.109 & 0.147 & 0.168 & 0.140 & 0.141 \\
\hline \multirow{2}{*}{\multicolumn{2}{|c|}{ L.S.D.(0.05) }} & \multicolumn{4}{|c|}{1.63} & 1.26 & \multicolumn{4}{|c|}{0.003} & 0.002 \\
\hline & & & & & & $\begin{array}{c}\text { Average of mulching } \\
\text { effect }\end{array}$ & & & & & $\begin{array}{c}\text { Average of mulching } \\
\text { effect }\end{array}$ \\
\hline \multirow{2}{*}{$\mathrm{M} \times \mathrm{Ca}$} & $\mathrm{M}_{1}$ & 42.91 & 54.27 & 62.22 & 53.44 & 53.21 & 0.095 & 0.120 & 0.138 & 0.118 & 0.118 \\
\hline & $\mathrm{M}_{2}$ & 46.00 & 60.93 & 68.26 & 57.35 & 58.13 & 0.102 & 0.135 & 0.151 & 0.127 & 0.129 \\
\hline \multicolumn{2}{|c|}{ L.S.D.(0.05) } & & \multicolumn{3}{|c|}{1.23} & 0.72 & \multicolumn{4}{|c|}{0.002} & 0.001 \\
\hline
\end{tabular}


The third interaction was no a significant effect in number and diameter of pods. The dates of sowing influenced in the quantitative yield characteristics. The third date plants significant superiority compared to the first and second date plants in these characteristics. Also the second date plants significant superiority as compared to the plants at the first date, but in a lower rate compared to the superiority of the plants at the third date. The increase in the quantitative yield characteristics of the third date plants may be due to the improvement in weather conditions from the temperature degree, relative humidity, ventilation and lighting surrounding the greenhouse in the period following that date during February and March. This improvement had contributed to the improvement of weather conditions surrounding the plant inside the greenhouse, therefore the temperature began to rise gradually up to the appropriate degree of growth $18-35^{\circ} \mathrm{C}$ (Abd El-Kader et al., 2010).

The low temperature caused slow in growth of plant and dwarfs pods (Matlub et al., 1989). The relative humidity was also ideal for plant growth. This improvement in temperature and humidity helps to get ventilation for a longer period of time by opening the doors and sides of the greenhouse and thus provide a greater opportunity to enter and renew carbon dioxide in to the greenhouse and increase the absorption of water and nutrients and improve the efficiency of photosynthesis process. Then increase the outputs of that process (carbohydrates), reduce injuries, increase vegetative growth and activity of plants, which was reflected positively in the improvement of characteristics of flowering growth, which increased the quantitative yield characteristics in the plants of the third date compared to the plants at the second date, which ranked order second in the improvement of quantitative yield characteristics of the product, which was closer to that improvement in weather conditions from the plants first date.

The results are agree with El-Waraky (2014); Ghodia et al. (2015); Atallah (2016) and Singh et al. (2018). The above tables also show that the mulching of the soil with the black polyethylene cover had a significant effect on the quantitative yield characteristics compared to without mulching soil. The reason for the superior mulching treatment that it was provided a good environmental conditions suitable for plant growth by raising soil temperature, improving physical and chemical properties, reduce water evaporation, increase retention of water and nutrient and facilitate plant absorption (Mahmood et al., 2002). Also mulching in black plastic contributes in remove the weeds, reduce its density, control and reduce competition to the main crop (Singh et al., 2010). That improves the growth and activity of the plant and increase the characteristics of vegetative growth, photosynthesis activity, the accumulation of nutrients (carbohydrates) and this leads to an increase the characteristics flowering and yield and its components. These results are agree with Firoz et al. (2007), Sonu et al. (2013), Ghodia et al. (2015) and Atallah (2016). The results of the previous tables confirm that foliar spraying calcium had a significant effect on quantitative yield characteristics and the most effective concentrations was $1 \mathrm{ml}^{-l^{-1}}$ followed by $0.5 \mathrm{ml} . \mathrm{l}^{-1}$, while the concentration of $1.5 \mathrm{ml} .1^{-1}$ was the less effective in these characteristics.

The significant effect of calcium can be attributed to his role which mentioned in 
advance that encourages and activates some enzymes lead to increased division of cell and increase the numbers and size of cell. It stimulates and encourages formation the walls of cells by entering into the structure of calcium Pectate, gaining hardness, regulating permeability, making more rubbery. And also influencing and stimulating on the formation of oxygen (IAA), which is present in the metastatic tissue (David, 2007). That increase new up growth and thus increase the characteristics of vegetative growth and this promotes and activates the process of photosynthesis, increase the accumulation of nutrients. The element of calcium works to raise the efficiency of the plant in the metabolism of carbon dioxide and participate in the transfer of carbohydrates from the places of composition in the leaves to places gathered in fruits (Abu Dhahi \& Al Yunis, 1988). That is reflected positively in the increase of flowering characteristics and then increase the quantity of yield and its components. The finding are in accordance with Abo-EI-Hamd \& Abd EI-wahed (2018).

\section{Conclusion}

We conclusion from this study that in order to obtain the best production according to the conditions of the experiment and as a result of the superiority of the plants at the third date in the quantity yield. It must be adopting the third date (15/1) for sowing the seeds of okra plant in the green houses and mulching the soil with the black polyethylene for the role that we mentioned previously. And foliar spraying by calcium fertilizer with a concentration of $1 \mathrm{ml}^{-1}$ and with three sprinkling after 40 days of planting seeds and ten days between the sprinkling and another.

\section{Acknowledgement}

The authors gratitude to the Department of Horticulture and Landscape, College of
Agriculture, University of Basrah for support this research work.

\section{References}

Abd El-Kader, A.A.; Shaaban, S.M. \& Abd El-Fattah, M.S. (2010). Effect of irrigation levels and organic compost on okra plants (Abelmoschus esculentus L) grown in sandy calcareous soil. Agric. Biol. J. North America, 1: 225-231.

Abdulla, A.A.; Hajji, J.H. \& Rassen, A.Z. (2017). Response of okra plants (Abelmoschus esculentus L) cultivated under low plastic tunnels to mulch soil and spray with licorice root extract and the growing top earring process, Univ. Karbala J. Sci., 15(3): 105-113. (In Arabic).

Abo EI-Hamd, A.S.A. \& Abd EI -Wahed, A. H.M. (2018). Improving the growth and yield of Okra (Abelmoschus esculentus) using Lithovit fertilizer, Academic J. Agri. Res., 6 (5): 65-71.

Abu Dahi, Y.M. \& Al Yunis, M.A. (1988). Plant Nutrition Directory, Min. High. Educ. Sci. Res., Univ. Baghdad: 411pp. (In Arabic).

AI-Sahaf, F.H. (1989). Applied Plant Nutrition, Dar Al Hekmah Press, Min. High. Educ. and Sci. Res., Iraq: 258pp. (In Arabic).

Al-Dajwi, A. (1996). Technology of Growing and Producing Vegetables, Madbouli Library. City: 448pp. (In Arabic).

Al-Rawi, K.M. \& Khalaf Allah, A.M. (1980). Designing and Analyzing Agricultural Experiments, Dar Al Kuttab foundation and Publishing Corporation, Univ. Mosul: 448 pp. (In Arabic).

Arab Organization for Agricultural Development (2016). The Year Book for 


\section{Alhamrani et al ./ Basrah J. Agric. Sci., 32(Spec. Issue 2):171-182, 2019}

Agricultural Statistics, vol. 36: 468pp. (In Arabic).

Atallah, S.Y. (2016). Performance of five Okra cultivars (Abelmoschus esculentus L) sown on different dates under Assiut environmental conditions, Assiut J. Agric. Sci., 47(6-1): 217-224.

David, J.P. (2007). Handbook Of Plant Nutrition-Philips. Morley Wight Salads Ltd. United Kingdom: 773pp.

El-Waraky, Y.B. (2014). Effect of sowing date, plant density and phosphorus fertilization on seed yield of okra (Abelmoschus esculentus L). Alex. J. Agri. Res., 59(1): 27-41.

Firoz, Z.A. ; Islam, M.A.; Mohiuddin, M. \& Rahman, M.M. (2007). Yield and yield attributes of okra (Abelmoschus esculentus L) as influenced by planting time and plant spacing in hill slope condition. Progress. Agric., 18(2): 67-73.

Ghodia, R.H.A.; Gomau, S.S. \& Elsagan, M.A.M. (2015). Early Production of Okra (Abelmoschus esculentus L.) Fruits under sima oasis conditions. Int. J. Adv. Res., 3(12): 210-216.

Mahmood, M.M.; Farooq, K.; Hussain, A. \& Sher, R. (2002). Effect of mulching on growth and yield of potato crop (Solanum tuberosum L.). Asian J. Plant Sci., 1(2): 132-133.

Marscher, P. (2012). Mineral Nutrition of Higher Plants. Elsevier, Ltd: 410pp.

Matlub, A.N.; Sultan, E.E. \& Abdoul, K.S. (1989). Production of Vegetables, Part 2, Univ. Mosul, Coll. Agric. Forestry, Univ. Mosul Publ.: 337pp. (In Arabic).

McCraw, B.D. (2003). Value of mulching soils easy gardening mulching, Texas Agricultural Extension Services. 4 pp.
Menegel, K.; Ernestand, E. \& Appel, O. (2001). Principles of Plant Nutrition, Kluwer Academic Publ.: 335 pp.

Ministry of Agriculture (2012). Directorate General of Planning and Follow-up, Agricultural Statistics Department-Iraq: 53pp. (In Arabic).

Mohammed, G.H. \& Saeid, A.I. (2017). Effect Of topping, humic acid, mulching color and their interactions on vegetative growth and seed yield of Okra (Abelmoschus esculentus L.). J. Univ. Duhok, 20(1): 41-49.

Saifulla, M. \& Rabbani, M.G. (2009): Evaluation and characterization of okra (Abelmoschus esculentus L. Moench.) genotypes. SAARC J. Agric., 7: 92-99.

Singh, H.M.; Mishra, U.S. \& Mishra, T.S. (2018). Effect sowing time and plant spacing on seed production in Okra (Abelmoschus esculentus L.) in Madhya Pradesh, J. Krishi Vigyan, 6(2): 78-80.

Singh, M.; Prabhukumar, S. \& Saifam, C.V. (2010). Integrated weed management in okra (Abelmoschus esculentus L. Moench). Ann. Plant Protect. Sci., 18(2): 481-483.

Sonu, J.P.S.; Nathlram, R. \& Kaushik, H. (2013). Effect of sowing dates and plant geometry on growth and yield of okra (Abelmoschus esculentus L) cultivar" parbhani kranti and pusaa-4" Asian J. Hort., 8(2): 772-774.

Zidan, G.J. ; Burhanuddin, A.R.H. \& Ayed, Q.Y. (2018). Evaluation of some of the varieties of okra ( Albamoschus esculentus L. Moench) cultivated on different dates under the conditions of the non-heated plastic house, Univ. Tikrit J. Agri. Sci., 18 (23): 69-76. (In Arabic). 